\title{
Glacier dynamics in the Susitna River basin, Alaska, U.S.A.
}

\author{
Ted S. Glarke \\ Geophysical Institute, University of Alaska Fairbanks, Fairbanks, Alaska 99775, U.S.A.
}

\begin{abstract}
The dynamics of the glaciers which form the headwaters of the Susitna River in central Alaska exhibit several interesting features, including a spectrum of surge-type behavior. A difference between balance flux and actual down-glacier transport, which is taken to be an indicator of surge behavior, shows West Fork Glacier and two tributaries of Susitna Glacier to be surge-type of varying strengths, while East Fork Glacier and one tributary of Susitna Glacier to be nonsurge-type. The main trunk of Susitna Glacier and its two unstable tributaries surge simultaneously with a period estimated to be 50-60 years. Having last surged in 1951-52, its next surge should be expected sometime in the first decade of the next century. West Fork Glacier last surged in about 1935 and again in 1987-88, indicating a similar surge period of about 50 years. Significant seasonal velocity variations were observed during the glacier's quiescent phases, with increases of 30$100 \%$ over background occurring early in the melt season. In some cases, the annual minimum occurred during late summer, implying that basal motion contributes measurably to winter velocity on at least some glaciers in the area. Events of rapid motion lasting a day or so also occur occasionally during the melt season and may account for brief velocity increases of up to $300 \%$.
\end{abstract}

\section{INTRODUCTION}

This paper presents measurements and observations on the glaciers that form the headwaters of Susitna River, located in central Alaska, U.S.A. (Fig. 1). Susitna River, the sixth largest in Alaska, drains a significant part of the south side of the Alaska Range. The study described here began as part of a proposed hydro-electric development project in the Susitna River basin (Harrison and others, 1983). The original purpose of the study was to determine how the glaciers within the basin affect run-off and sediment supply in Susitna River (Clarke and others, 1985, 1986; Clarke, 1986). (For economic reasons, the hydro-electric project never progressed beyond the planning stages.)

Five large glaciers and 50 or 60 small glaciers form the headwaters of Susitna River. The five major glaciers are Susitna, West Fork, "East Fork", Maclaren and Eureka Glaciers (Fig. 1). Maclaren and Eureka Glaciers feed the tributary Maclaren River. This paper focuses on the dynamics of Susitna Glacier and its tributaries, West Fork and East Fork Glaciers. Measured ice flux is compared to balance flux, and the equilibrium between the two (or the lack thereof) is taken to be an indicator of surge behavior. Supporting evidence for this interpretation of the flux comparison is provided by an evaluation of moraine patterns on pre- and post-surge aerial photographs of Susitna Glacier, and from a comparison of surface-elevation changes on the glacier since its last surge. The periodicity of glacier surges in the basin is also estimated.

As stated above, some glaciers in the area are surgetype. Prior work on glacier surges includes a summary of the variability and periodic nature of surges by Meier and Post (1969). The studies of Dolgushin and Osipova $(1973,1978)$ on Medvezhy Glacier, of Krenke and Rototaev (1973) on Kolka Glacier, and of Clarke and others (1984) on Trapridge Glacier have improved our understanding of glacier surges. Detailed observations on Variegated Glacier before, during and after its 1982-83 surge have lent insight into the evolution of glacier geometry during a surge cycle (Raymond and Harrison, 1988) and the mechanisms that lead to and maintain rapid glacier motion during a surge (Kamb and others, 1985). And, most recently, observations of the 1986-87 surge of Peters Glacier (Echelmeyer and others, 1987) and the 1987-88 surge of West Fork Glacier (Echelmeyer and Harrison, 1989) have shown some of the similarities and differences between surges on different glaciers.

While these studies have led to significant developments in the understanding of glacier surges, there remain relatively few direct measurements on surge-type glaciers. The intent of this paper is to provide further information and understanding of this aspect of glacier dynamics and glacier dynamics in general. A brief discussion of previous work in the Susitna Glacier basin and 


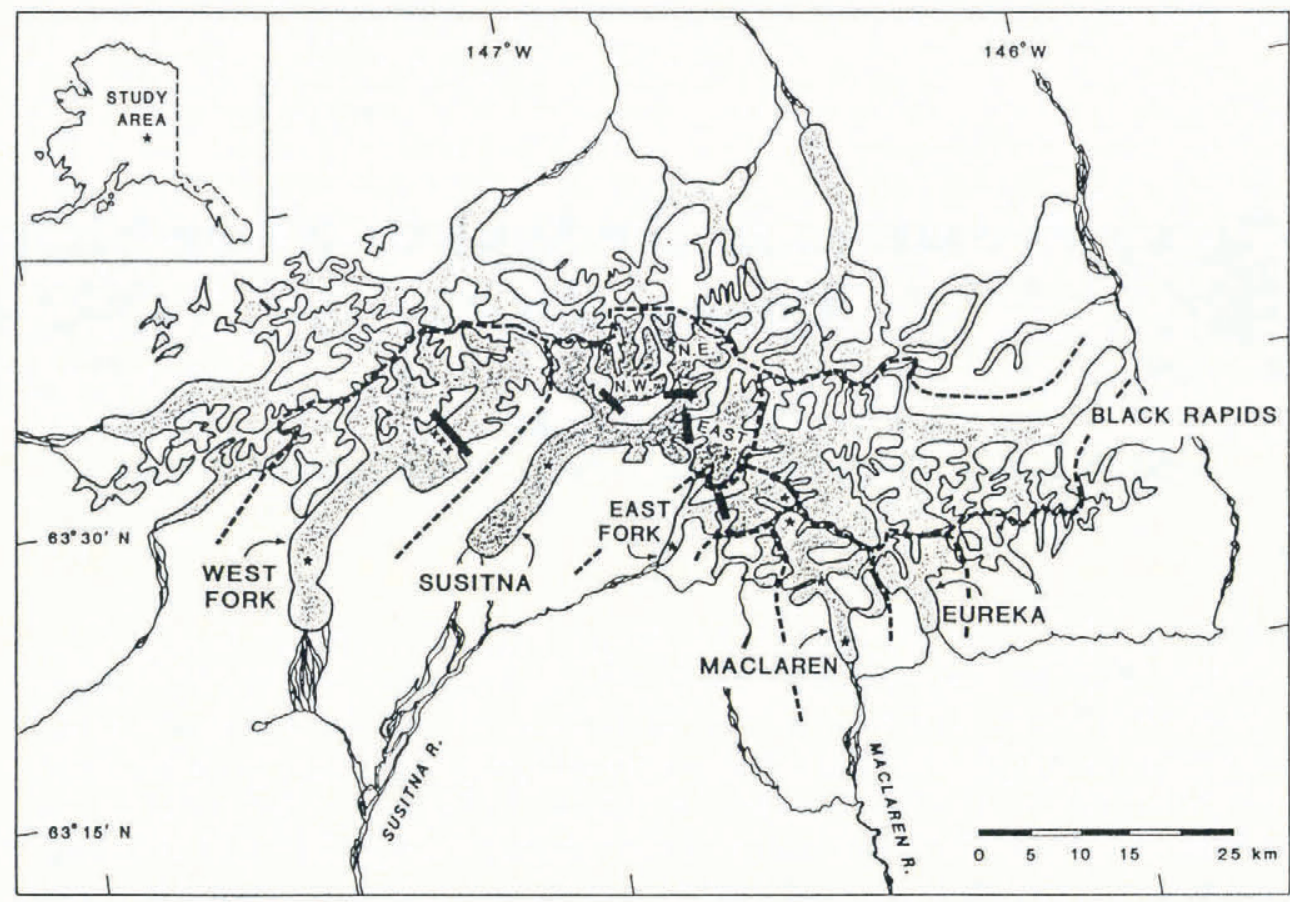

Fig. 1. Glacier location map. The three tributaries of Susitna Glacier under discussion are labeled accordingly. Balance flux and actual flux are estimated at the constrictions marked by the black transverse bars. Asterisks denote accumulation- and ablation-stake locations. The transverse bars cover the points where velocity was measured. The dashed line denotes drainage divides. The cross-section on West Fork Glacier where depth has been measured is marked by a row of Xs.

a history of glacier surges in the basin opens the discussion.

\section{PREVIOUS WORK AND SURGE HISTORY}

Susitna Glacier is roughly $35 \mathrm{~km}$ long and covers about $230 \mathrm{~km}^{2}$. It is a geometrically complex glacier (Fig. 1) and is well known to be of surge-type (Post, 1960, 1969). Post (1960) estimated that the last surge occurred in 1952 or 1953 with ice displacements of about $4 \mathrm{~km}$. Post estimated the displacements from oblique aerial photographs taken in 1942 (B. Washburn; Boston Museum of Science) and U.S. Geological Survey (USGS) vertical aerial photographs taken in July 1954. Since the study of Post (1960), other aerial photographs have been located. Photographs taken on 29 August 1949 (USGS) show no signs of surging, and photographs taken on 5 July 1952 (USGS) show the surge front about $400 \mathrm{~m}$ from its July 1954 position. With these further time constraints, it appears that the surge had nearly ended by mid-summer 1952 and was initiated no earlier than winter 1949-50. The surge propagated a considerable distance into previously stagnant ice, but stopped $2 \mathrm{~km}$ short of an earlier surge. No other historical observations of Susitna Glacier prior to 1942 are known to exist, and the glacier has not surged since 1952 .

West Fork Glacier, $40 \mathrm{~km}$ long and covering about $257 \mathrm{~km}^{2}$, was first identified as surge-type by Post (1969). This glacier is perhaps less known as surge type but has, in fact, just ended a spectacular surge. Hints" of an impending surge were first noticed by A. Post and B. Krimmel during a photographic flight in late August 1987 (Post, USGS internal memorandum, 1988). In early
January of the following year, Echelmeyer and Harrison (1989) noticed extensive shearing along the glacier margins. By February they found the glacier was clearly undergoing a strong surge with draw-down having propagated far into the accumulation area, and previously stagnant ice was being activated by a well-defined surge front. In total, when the surge terminated in early July 1988 , about $35 \mathrm{~km}$ of the glacier length had been activated. A detailed study of this surge (personal communication from W. Harrison and K. Echelmeyer) and its effects on the sediment budget of Susitna River (personal communication from C. Raymond, R. Benedict and E. Chaco) is currently in progress. Post (written communication to S.C. Wilbur, 1984) estimated the previous surge of West Fork Glacier to have occurred in approximately 1937. This was estimated from oblique acrial photographs taken by B. Washburn in July 1940. Judging from the extremely crevassed nature of the present glacier surface (2 years after surge termination) and the comparatively smooth "healed" surface depicted in the 1940 photographs, Post's assessment that a surge had occurred 3 years prior to 1940 may be an underestimate. It appears more likely that the surge had occurred perhaps 5 years prior to 1940, placing it in roughly 1935 rather than 1937.

No other photographic information prior to 1940 is known to exist on West Fork Glacier except for a few ground photographs taken in August 1913 by the F. H. Moffit (USGS) railroad survey parties. These photographs show no evidence of active surge. However, a careful examination of color infrared stereo photographs taken by the National Aeronatics and Space Administration (NASA) in 1980 reveals three successively younger 


\section{WEST FORK GLACIER}

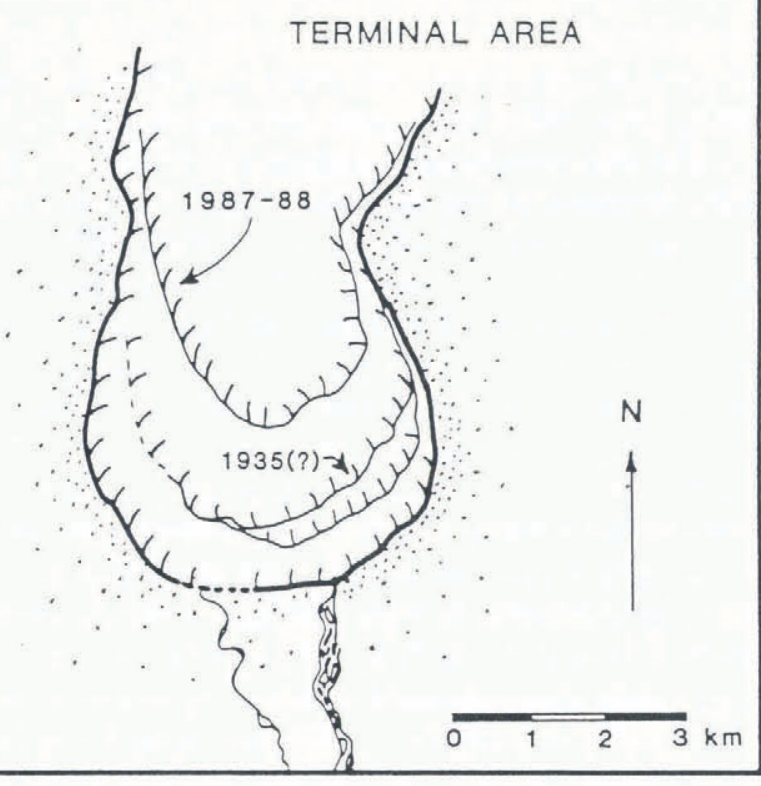

Fig. 2. Terminal moraine positions of West Fork Glacier. The ages of the two most extended surge positions could not be determined. The westernmost channel depicted here was the primary drainage prior to, during and after the 1987-88 surge. (From 1980 NASA and 1989 University of Alaska photographs.)

and less extended surge terminal positions (Fig. 2). About $0.5 \mathrm{~km}$ separates each terminal position. Progressing upvalley, each terminal moraine (and the ground behind it) shows an essentially uniform stability and age of vegetation. Since there is no evidence of active surge on any photographs taken since 1940 (USGS, 1949, 1954, $1963,1971,1980)$, the least-extended and least-vegetated of these termini can be identified as a remnant of the 1935(?) surge. The 1987-88 surge fell about $1.1 \mathrm{~km}$ short of this most recent moraine.

East Fork Glacier is smaller and geometrically simpler than either Susitna or West Fork Glaciers. It is about $18 \mathrm{~km}$ long and covers $42 \mathrm{~km}^{2}$. East Fork Glacier has been examined by several authors, each of whom concluded that it is not a surge-type glacier. Post (1969) determined this from the examination of historical aerial photographs and many years of observations. Harrison and R \& M Consultants (1982) concluded this after comparing the 1949-80 displacement of a distinct marker on the glacier surface (a rock slide) to the glacier center-line velocity surveyed in late summer 1982 . The $1949-80$ displacement was measured from aerial photographs. The surveyed velocity fell within $1 \%$ of the average 1949-80 velocity, and from this they concluded it was unlikely that a major surge took place between 1949 and 1980 . Wilbur (1988) also concluded this after an extensive examination and comparison of hundreds of aerial photographs in the USGS photographic libraries. Using the designations set forth in the Canadian Glacier Inventory (Ommanney, 1980), Wilbur assigned East Fork Glacier a surge code of 1 on a 0 to 5 point scale. (The Canadian
Glacier Inventory assigns 0 to a glacier with no special surge features and assigns 5 to a glacier that is certain to be of surge type (G.K. C. Clarke and others, 1986). In the same work, for comparison, West Fork Glacier was assigned a code of 4 and Susitna Glacier a code of 5 .

Eureka and Maclaren Glaciers are similar to East Fork Glacier in size and complexity. Eureka Glacier is about $11 \mathrm{~km}$ long and covers $39 \mathrm{~km}^{2}$; Maclaren Glacier is about $19 \mathrm{~km}$ long and covers $59 \mathrm{~km}^{2}$. Less is known of the history of these two glaciers. Eureka Glacier is listed as surge type and Maclaren Glacier is listed as inconclusive by Post (1969). Mayo (1978) noted that Maclaren Glacier underwent a weak surge or strong "pulse" in 1971. A mid- to late-summer ground-based photograph of Maclaren Glacier taken by Moffit (USGS) in 1910 or 1911 shows what appears to be fresh crevassing in the terminal area, but the photograph is very low angle, making it difficult to interpret definitively. Wilbur (1988) assigned a Canadian Glacier Inventory code of 2 to Eureka Glacier and a code of 3 to Maclaren Glacier.

\section{METHODS}

Field measurements for this project were undertaken during the 1981, 1982 and 1983 field seasons. Stakes were drilled into the glacier surfaces at approximately 1100,1500 and $2000 \mathrm{~m}$ elevations to monitor point balance and velocity. One stake was maintained at each of these elevations on both West Fork and East Fork Glaciers. Susitna Glacier was studied somewhat more intensively because of its known surge history, and because of its complexity. Each of its three tributaries was monitored individually with separate 1500 and $2000 \mathrm{~m}$ elevation stakes for each. The tributaries share a common ablation area and therefore had a common $1100 \mathrm{~m}$ elevation stake. Velocity was measured at the mid-elevation stakes only. Also, the mid-elevation stakes were located at valley constrictions (Fig. 1) which enabled ice flow through a simple cross-section to be estimated. The constrictions were chosen as close to the equilibrium lines as possible (usually about 150-200 $\mathrm{m}$ below the average equilibriumline altitude), so balance flux through the cross-section would be a maximum. In 1982, helicopter altimetry was used to record glacier-surface elevation near several of the stakes. Elevations were measured in mid-May and on 20 September. The altimeter was calibrated on points of known elevation during the surveys. Owing to logistical difficulties, velocity information was not collected on Maclaren or Eureka Glaciers.

\section{Glacier velocity}

Glacier center-line velocity was measured at the midelevation markers by theodolite resection, and by timelapse photography for a brief interval on East Fork Glacier as described by Harrison and others (1986a). Surveys at the beginning and end of the melt season provided winter and summer velocities, and mid-summer surveys provided velocity fluctuations during the melt season. Velocities derived from these surveys are shown in Figure 3; those from the time-lapse photography (Harrison and others, 1986b) are given in Figure 4.

Figure 3 shows that the glaciers of the Susitna River basin, like many temperate glaciers, undergo significant seasonal velocity variations. Increases in velocity during 


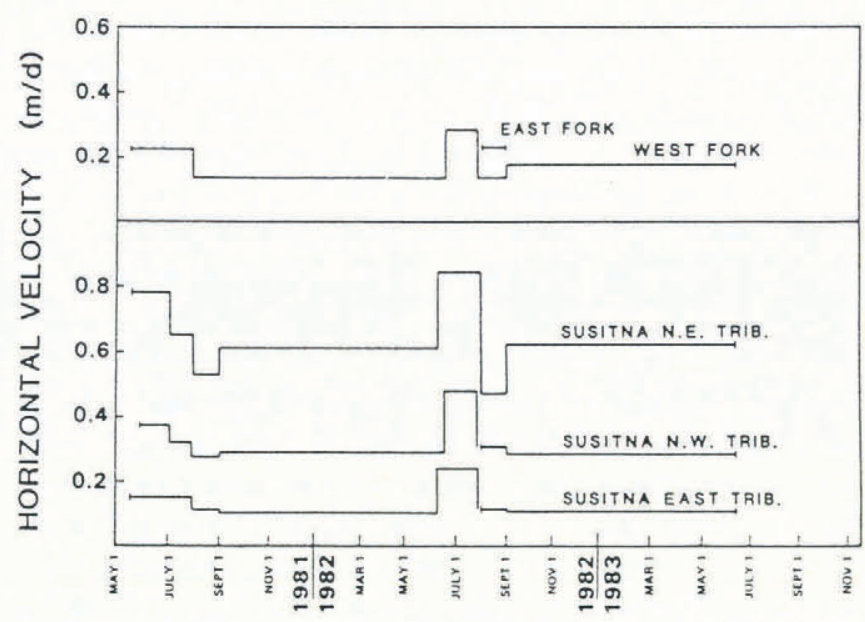

Fig. 3. Glacier velocity versus time. (Modified from Harrison and $R \& M$ Consultants, 1982.)

the early part of the melt season caused up to a doubling of glacier velocity. A perhaps more interesting observation is that the lowest measured velocities on West Fork Glacier and two tributaries of Susitna Glacier occurred late in the melt season, rather than in the winter. The limited data in Figure 4 show that short-lived events of rapid motion also occur, as is common with other temperate glaciers (Iken, 1977; Iken and others, 1983; Harrison and others, 1986a, b). The event in Figure 4 occurred late in the melt season against a background of slowly decreasing velocity.

The early melt-season velocity peak and late meltseason minimum have important implications for basal motion. Since the glaciers thin during the melt season

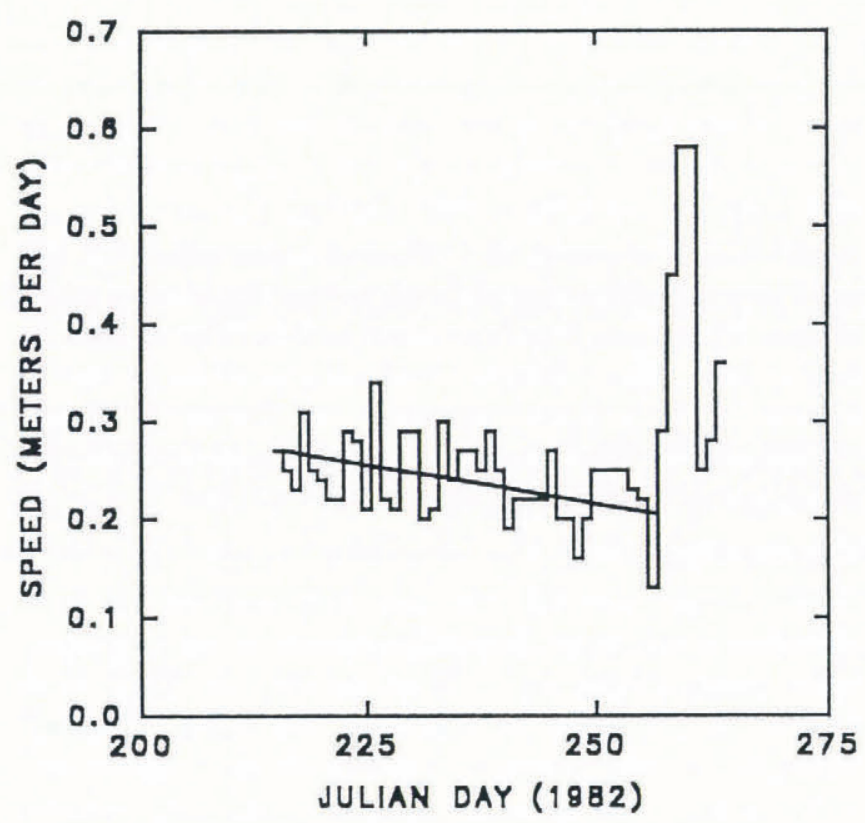

Fig. 4. Velocity on East Fork Glacier as measured by time-lapse photography on a daily basis between Julian days 214 and 256 (1 August-12 September) 1982. A linear fit to the data, which are somewhat noisy, shows the trend prior to the motion event. (From Harrison and others, 1986b.) (at least in the area where velocity was measured), the increase in speed during the early part of this season must be due to enhanced basal motion. This enhanced sliding is thought to be caused by increased meltwater input and storage within the glacier and at its bed (Hodge, 1974; Iken, 1977, 1981; Iken and others, 1983).

The late melt-season minimum is not as well known. The increased speed in winter cannot be explained by increased loading of the glaciers during winter. Average balance in the vicinity of the velocity stakes during the winter season ( 1 October-14 May) varied between +0.75 and $+1.25 \mathrm{~m}$ ice equivalent, depending upon the glacier and year of measurement (Clarke, 1986). This thickening is very small compared to the $400-700 \mathrm{~m}$ ice thicknesses at the velocity markers, and can at best only account for a few per cent of the winter-speed increase. This implies that, at least on the glaciers that show a velocity minimum in late summer, some of the winter motion is due to sliding. (It should be noted, however, that these seasonal velocity variations were only measured near (slightly below) the equilibrium lines on each glacier and may vary considerably elsewhere on each glacier.) Hodge (1974) observed a similar velocity minimum on Nisqually Glacier during the same season and, using essentially the same approach, found that changes in ice thickness could not explain its speed increase during winter. Rather, Hodge concluded that the only viable explanation for this speed-up was a steady increase in stored water at the glacier bed throughout the winter.

\section{Comparison of balance flux to actual flux}

We wish to compare mass balance above each velocity marker (balance flux) to ice flow (actual flux) at the respective velocity markers. For a glacier to be in flow equilibrium, the balance flux must equal the actual flux through the constrictions where velocity was measured. In order to determine the balance flux from measurements of accumulation, the time period over which mass balance is measured must be long enough to smooth out seasonal and annual variations in balance. Similarly, for an accurate determination of ice transport by glacier flow, the time period over which velocity is measured must be long enough to average out seasonal variations in velocity. In the discussion below, balance flux is estimated from 3 years of annual balance data, and actual flux is estimated from 2 years of velocity data.

\section{Balance flux}

The point-balance data collected from the stake network described above were used to construct annual balance versus elevation curves. Details of how these curves were constructed have been described by Clarke (1986). The balance year was taken to be 1 October-30 September. Area-elevation relations for each glacier were determined from 1:63360 scale USGS topographic maps. Total annual balance above each velocity point for each year, $B_{\mathrm{a}}$, could then be determined from the relation:

$$
B_{\mathrm{a}}=\sum_{i=1}^{m} b_{i} a_{i}
$$

where $b_{i}$ is the annual balance per year in the $i$ th elevation interval, $a_{i}$ is the area of the $i$ th elevation element above the velocity gate, and $m$ is the highest elevation 
Table 1. Total annual ice balance above constrictions

Glacier

Total annual balance

$10^{6} \mathrm{~m}^{3} \mathrm{a}^{-1}$ ice

$1981 \quad 1982 \quad 1983 \quad 3$ year average

West Fork

108.4

91.6

$125.8 \quad 108.6$

Susitna,

$\begin{array}{lcccc}\text { East tributary } & 55.8 & 38.0 & 79.3 & 57.7 \\ \text { Northeast tributary } & 98.6 & 77.4 & - & - \\ \text { Northwest tributary } & 23.9 & - & - & -\end{array}$

East Fork

25.7

29.8

element in the basin being considered. The results of these calculations are shown in Table 1.

As stated previously, total annual balance above a given cross-section, when averaged over several years, is approximately equal to balance flux. Unfortunately, the 1983 balances were not obtained for the northeast (locally referred to as "Turkey") and northwest tributaries of Susitna Glacier because these accumulation-area stakes were buried by high snowfall that year. (This high snowfall is reflected in the balance data for the three glaciers that do have 1983 data.) If Table 1 is examined closely, it can be seen that the 1981 total annual balance is nearly equal to the 3 year average for West Fork and Susitna Glaciers' east tributary, which have complete 3 year data. The balance-flux estimates (shown in Figure 5) are thus taken to be equal to the 1981 total annual balance for the northeast and northwest tributaries (which lie geographically between West Fork and the east tributary); West Fork and Susitna Glaciers' east tributary balance fluxes are taken to be equal to the 3 year averages and, since there are no 1981 data for East Fork

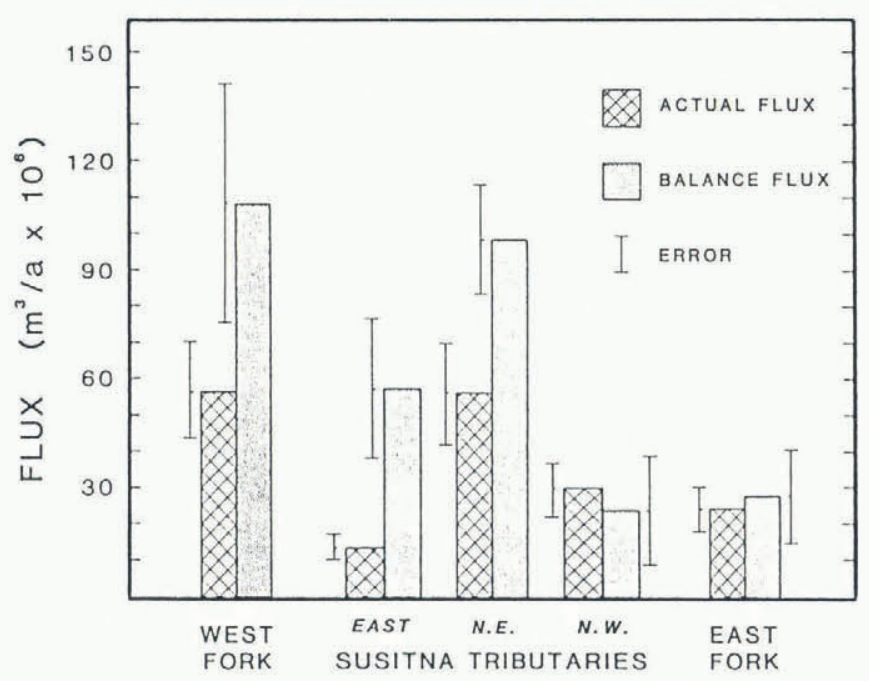

Fig. 5. Comparison of actual flux and balance flux.
Glacier, its balance flux is taken to be the average of the 1982 and 1983 total annual balances.

Actual flux

Actual flux, $Q_{\mathrm{a}}$, can be approximated from the relation:

$$
Q_{\mathrm{a}}=A\left\{u_{\mathrm{b}}+S\left(u_{\mathrm{s}}-u_{\mathrm{b}}\right)\right\}
$$

where $u_{\mathrm{s}}$ and $u_{\mathrm{b}}$ are the surface and basal velocity at the center line, respectively; $A$ is the cross-sectional area and $S$ is a velocity shape factor. Channels were assumed to be parabolic with center-line depth $h$ (determined below). The velocity shape factor was taken to be about 0.67 following Nye (1965). In all cases, $u_{\mathrm{s}}$ was averaged over integral years as nearly as possible $(2.04-2.08$ a) to reduce errors in average speed due to seasonal variations. Deformational velocity $\left(u_{\mathrm{s}}-u_{\mathrm{b}}\right)$ was assumed to be equal to the lowest measured velocity on each glacier, and any increase in velocity over the lowest measured velocity was assumed to be caused by sliding. Velocity measurements from July 1981 to June 1983 were used in the calculation. The results of the actual flux estimates, shown in Figure 5, are averages over this 1981-83 period.

Maximum glacier depth, $h$, was not measured during this study and therefore had to be approximated from the relation:

$$
h=\left(\frac{(n+1)\left(u_{\mathrm{s}}-u_{\mathrm{b}}\right)}{2 A(f \rho g \sin \alpha)^{n}}\right)^{1 /(n+1)}
$$

where $n$ and $A$ are flow-law parameters, set equal to 3 and $1.67 \times 10^{-7} \mathrm{a}^{-1} \mathrm{kPa}^{-3}$, respectively (from Paterson, $1981), f$ is the stress-shape factor (Nye, 1965), $\rho$ is ice density, $g$ is the acceleration of gravity, and $\alpha$ is surface slope taken from USGS $1: 63360$ scale maps as averaged over about 15 ice thicknesses. The shape factor is dependent upon the ratio of width to depth, and depth is unknown, so the solution for $f$ and $h$ must be determined iteratively. The resulting values of $f$ are in the range of $0.50-0.57$, with corresponding half-width to depth ratios varying from 1.23 to 1.52 .

The parameter $A$ was assumed to be that of temperate ice. A thermocouple string was placed $20 \mathrm{~m}$ deep high ( $2350 \mathrm{~m}$ elevation) on the northwest tributary of Susitna Glacier on 22 May 1981. By 3 August, the sensors showed isothermal conditions to at least this depth (Harrison, 1981). Given existing ideas on heat transfer in glaciers (e.g. Paterson, 1981, chapter 10), it is reasonable to infer from this that the majority of the ice in the basin is temperate. Also, earlier work by Harrison and others (1975) found nearby Black Rapids Glacier to be essentially temperate. Harrison and others (1975) did, however, find a roughly $15 \mathrm{~m}$ thick $-1^{\circ}$ to $-2^{\circ} \mathrm{C}$ surface layer in the Black Rapids Glacier ablation area. These layers are common and are attributed to the inability of meltwater to percolate downward and rewarm the ablation area in spring (Paterson, 1972). A similar cold layer probably also exists on the lower reaches of the Susitna basin glaciers but was not considered extensive enough to have a significant effect on flow. (Note that Black Rapids, Susitna and East Fork Glaciers all share the same ice field but flow in different directions (Fig. 1).)

Velocity data from East Fork Glacier were obtained 
Table 2. Estimated maximum ice thickness in cross-sections

\begin{tabular}{|c|c|c|c|c|}
\hline Glacier & $\begin{array}{c}\text { Deformation } \\
\text { velocity }\end{array}$ & $\begin{array}{c}\text { Surface } \\
\text { slope }\end{array}$ & $\begin{array}{c}\text { Stress-shape } \\
\text { factor }\end{array}$ & $\begin{array}{c}\text { Maximum } \\
\text { ice } \\
\text { thickness }\end{array}$ \\
\hline & $\begin{array}{c}u_{s}-u_{\mathrm{b}} \\
\mathrm{m} \mathrm{a}^{-1}\end{array}$ & $\alpha$ & $f$ & $\begin{array}{l}h \\
\mathrm{~m}\end{array}$ \\
\hline West Fork & $\begin{array}{l}50.7 \\
\text { (measured }\end{array}$ & $\begin{array}{l}0.0231 \\
\text { maxim }\end{array}$ & $\begin{array}{c}0.55 \\
\text { um, radio ec }\end{array}$ & $\begin{array}{r}810 \\
\text { ho: } 675)\end{array}$ \\
\hline \multicolumn{5}{|l|}{$\begin{array}{l}\text { Susitna, } \\
\text { East }\end{array}$} \\
\hline $\begin{array}{l}\text { Northeast } \\
\text { tributary }\end{array}$ & 172 & 0.0837 & 0.56 & 410 \\
\hline $\begin{array}{l}\text { Northwest } \\
\text { tributary }\end{array}$ & 101 & 0.0631 & 0.54 & 460 \\
\hline East Fork & 86.1 & 0.0673 & 0.56 & 410 \\
\hline
\end{tabular}

in late summer only and are insufficient to determine its pattern of seasonal velocity variation. For the purpose of calculating ice depth, East Fork Glacier was assumed to be similar to the surrounding glaciers, so the late summer velocity given in Figure 3 was taken to be entirely due to internal deformation, realizing that the actual pattern is complicated by the occurrence of short-period motion events (Fig. 4). Since it was also necessary to use this same velocity in the calculation of actual flux, the re-

Table 3. Estimated actual ice flux per year through the crosssections. Actual flux shown here is the July 1981-June 1983 yearly average

Glacier

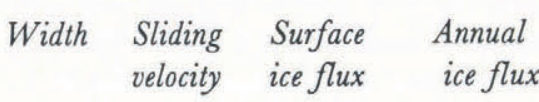

$\begin{array}{cccc} & u_{\mathrm{b}} & u_{\mathrm{s}} & Q_{\mathrm{a}} \\ \mathrm{m} & \mathrm{m} \mathrm{a}^{-1} & \mathrm{~m} \mathrm{a}^{-1} & \mathrm{~m}^{3} \mathrm{a}^{-1} \times 10^{6} \\ & & & \\ 2320 & 11.5 & 62.2 & 56.6 \\ 2320 & 25.5 & 62.2 & (56.0)^{*}\end{array}$

Susitna,

$\begin{array}{lrrrr}\text { East tributary } & 1280 & 5.3 & 43.6 & 13.7 \\ \text { Northeast tributary } & 1200 & 57.6 & 229.6 & 56.1 \\ \text { Northwest tributary } & 1280 & 8.8 & 109.8 & 29.8\end{array}$

$\begin{array}{lllll}\text { East Fork } & 1210 \quad ? & 86.1 & 24.2\end{array}$

* $Q_{\mathrm{a}}$ and $u_{\mathrm{b}}$ estimated from measured depth. sulting flux would be a minimum since seasonal sliding had not been included. Flux due to sliding for the other four glaciers averaged about $22 \%$ of the total flux, so a similar adjustment was made to the East Fork Glacier result. The results of the depth calculations are shown in Table 2, and the final actual flux estimates are shown in Table 3 .

An independent check on the reliability of the depth estimates can be obtained by a comparison with a crosssection on West Fork Glacier where ice depth has recently been measured. The cross-section is located about $1 \mathrm{~km}$ down-glacier of the velocity measurement point (Fig. 1) and is approximately parabolic, as assumed in the calculations above. Ice depths, provided by B. Weertman (written communication, 1990) were measured by radio-echo sounding. The measured maximum depth, $675 \mathrm{~m}$, and calculated depth, $810 \mathrm{~m}$, agree reasonably well (Table 2).

It should be noted that the actual flux results are relatively insensitive to the partitioning of the motion between deformation and sliding. This is because, for example, an underestimate of basal sliding lowers average sectional velocity (Equation (2)), but this also leads to an overestimate of internal deformation and therefore an overestimate of maximum glacier depth (Equation (3)). These two effects tend to cancel themselves (within 10\%). West Fork Glacier serves as a good example. If West Fork Glacier's flux is determined from the $675 \mathrm{~m}$ measured thickness and "true" sliding velocity (i.e. any velocity not explained by glacier thickness and slope), $Q_{\mathrm{a}}=56.0 \times 10^{6} \mathrm{~m}^{3} \mathrm{a}^{-1}$ results. If the same calculation is performed using the $810 \mathrm{~m}$ calculated depth, and the assumed sliding velocity (i.e. any velocity over the minimum measured velocity, $Q_{\mathrm{a}}=56.6 \times 10^{6} \mathrm{~m}^{3} \mathrm{a}^{-1}$ results.

\section{DISCUSSION}

The estimates of actual flux and balance flux are compared in Figure 5. Table 4 shows the ratios of actual flux to balance flux. A ratio of 1.00 means the glacier is transporting its accumulated mass down-glacier each year. This is interpreted to mean that a particular glacier is not building a reservoir of ice which could, for example, be released during a surge. From Figure 5 it is clear that three of the five glaciers listed show a significant imbalance between actual flux and balance flux. The east tributary of Susitna Glacier shows the greatest disequi-

\section{Table 4. Ratio of actual flux to balance flux}

Glacier West Fork Susitna Glacier tributaries

East Fork

East Northeast Northwest 


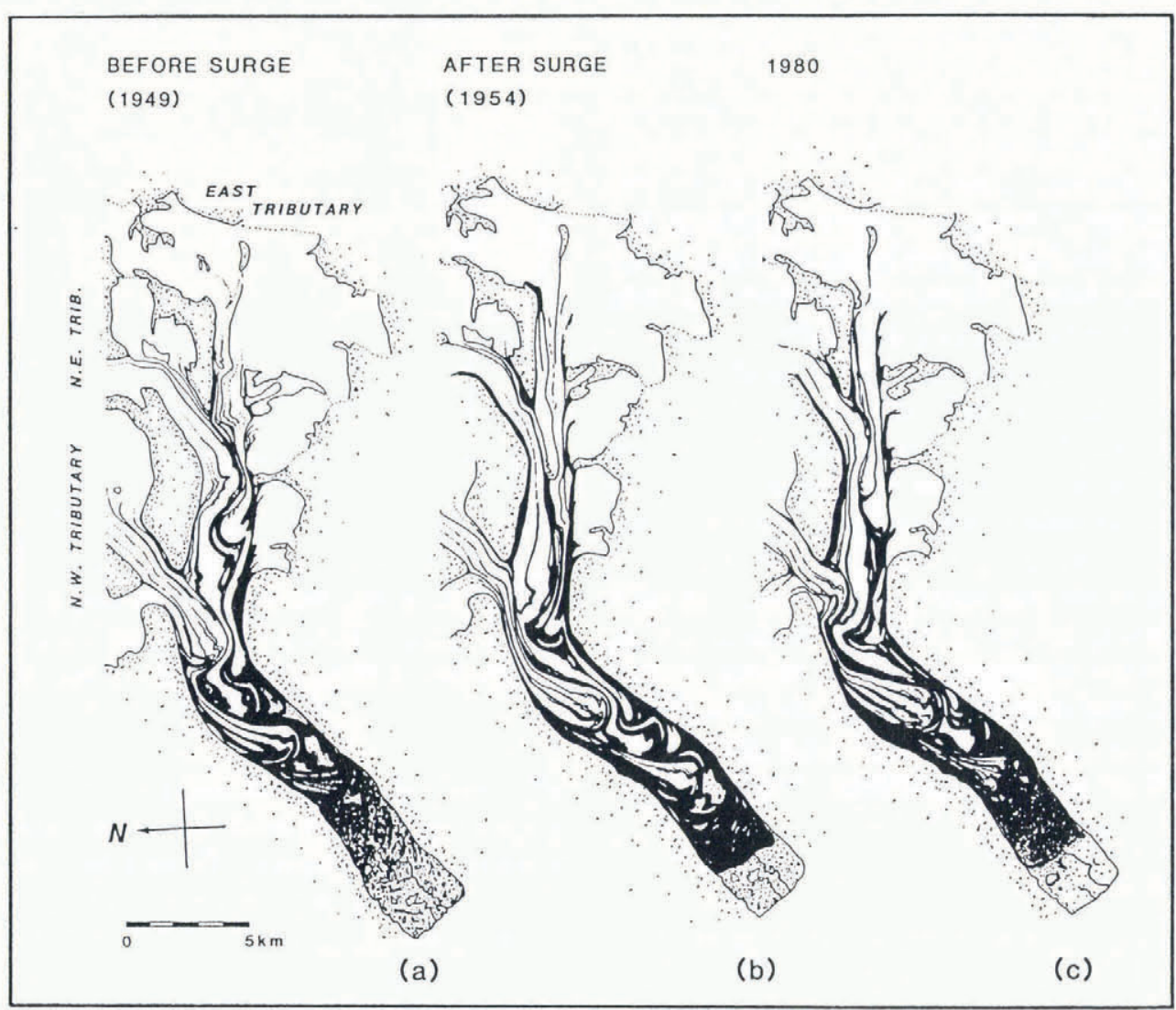

Fig. 6. Evolution of moraines on Susitna Glacier. Left and center are from Meier and Post (1969). Note that the 1951-52 surge did not extend as far as the prior surge. (Modified from Harrison and others, 1983.)

librium with only about $24 \%$ of the accumulation being transported out of that basin. West Fork Glacier and the northeast tributary of Susitna Glacier show transports of $44 \%$ and $57 \%$, respectively. The northwest tributary and East Fork Glacier show no discernible imbalance.

It is important to realize that an inequality between balance flux and actual flux does not necessarily imply that a glacier is building toward a surge. Holmlund (1988), using a similar comparison on Storglaciären, Sweden, found that a disequilibrium occurred there because of changes in mass balance on the glacier. However, prior surge history and other evidence (discussed below) indicate that the imbalance measured here is more likely caused by a rebuilding between surges rather than a change in mass balance.

The ratios listed in Table 4 for Susitna Glacier apparently indicate that its northwest tributary contributes little to a surge; its east tributary contributes significantly, and its northeast tributary apparently lies somewhere between these two. (It should be noted, however, that the disequilibrium of the northeast tributary is similar to that of West Fork Glacier which just underwent a strong surge.)

Other evidence for the relative surge strength of these tributaries can be found by examining moraine structures in sequential aerial photographs. Figure 6 shows the evolution of moraine patterns from just before the 1951-52 surge to just after the surge and their appearance in 1980. In 1949, the moraines of the northwest tributary show it to be flowing vigorously into the rela- tively sluggish main trunk; this lobe was sheared off and carried down-glacier by the 1951-52 surge, and the lobe again grew steadily after the surge until at least 1980 . Note that this tributary contributed little to the surge. The northeast tributary appears to show a similar vigorous flow prior to the surge. It did, however, contribute a significant amount of ice to the surge as is shown in the 1954 photograph (Fig. 6b). This reflects its intermediate surge character. The relatively stagnant east tributary became active only during surge, reflecting its strong surge character.

It is arguable that, if both the northeast and east tributaries show significant participation during a surge, then one tributary does not necessarily surge more strongly than the other. However, if one tributary lies nearly stagnant between surges, and the other continues to flow rather normally, then the two are different in their overall dynamics.

According to Figure 5 and Table 4, the accumulation area of Susitna Glacier's east tributary should be thickening. As mentioned previously, glacier center-line surface elevation on this branch was measured in 1982. A comparison of the altimetry data and map-elevation data is shown in Figure 7. In the vicinity of the accumulation stake, this tributary did indeed thicken by approximately $60 \mathrm{~m}$ between 1956, when the glacier was mapped (written communication from M. Southern, 1984), and 1982. The question arises as to whether this rate of thickening is in agreement with the expected rate of thickening due to the inequality between actual flux and balance flux. 
If the distribution of thickness change is integrated over the area of the glacier above the velocity marker (over only that area affected by the 1951-52 surge), an average ice-thickness change of $+0.80 \pm 0.32 \mathrm{~m} \mathrm{a}^{-1}$ results for the 1956-82 period. This is to be compared with the $+0.92 \pm 0.44 \mathrm{~m} \mathrm{a}^{-1}$ difference between balance flux and actual flux for the 1981-83 period in the same basin. Although the two rates of thickening are averages over different times in the surge cycle, the similarity between them shows the flux comparison to be reasonable.

The disequilibrium of West Fork Glacier is confirmed by its 1987-88 surge. If Figure 3 is examined, it is clear that West Fork Glacier's velocity, excluding the spring speed-up period, increased substantially between 198182 and 1982-83. Since glacier slope and thickness did not change appreciably over this 1 year period, this $29 \%$ increase is very likely due to an increase in basal sliding. It is interesting that Variegated Glacier showed a very similar speed increase of about $26 \%$ annually, at a similar location on the glacier, during the 7 years prior to its 1982-83 surge (Raymond and Harrison, 1988).

\section{SURGE PERIOD}

How often may surges be expected to occur in the Susitna River basin? West Fork Glacier surged in about 1935 and again in 1987-88, indicating a surge period of about 50-60 years. Based on the information discussed above, it appears likely that Susitna Glacier is also readying for another surge. Estimates of its surge period can be obtained in at least two ways, both of which are founded upon the non-surge behavior of the northwest tributary.

First, there is an icefall in the northwest tributary that produces ogives. Ogives are known to form on an annual basis (Nye, 1958). By 1949, roughly $47( \pm 5)$ of these ogives had crossed from the tributary into the main glacier (USGS photograph, 1949). If it is assumed that, as in 1951-52, this lobe was sheared off and carried down-glacier by the surge prior to 1951-52, it appears that the new lobe had been forming for about 47 years by 1949 . Since the glacier surged 2 or 3 years later, a period of about 50 years is indicated.

The second estimate can be obtained by simply comparing the area of this same lobe just before the 1951-52 surge to the area of the new lobe in 1980. The pre-surge lobe covered an area of $4.0 \mathrm{~km}^{2}$ in 1949 . By 1980 the new lobe had grown to $2.0 \mathrm{~km}^{2}$. The ratio of these areas multiplied by the time it took the new lobe to grow to its 1980 size yields a similar surge period of roughly 56 years.

It is also reasonable that surge period and flux imbalance are related. Unfortunately, flux imbalance has large temporal and spatial dependences associated with it. For example, Bindschadler and others (1977) found Variegated Glacier to have a flux imbalance (in the mid1970 s) of about $7: 1$, but by 1981 its imbalance had decreased to about $2.6: 1,1$ year before the glacier surged (from Raymond and Harrison, 1988). It seems then that a glacier's flux imbalance can only be related to surge period if the variation in the imbalance is known over most of the quiescent phase. Also, the two fluxes must be compared near the lower reaches of the surge supply area (if the fluxes were compared above the supply area

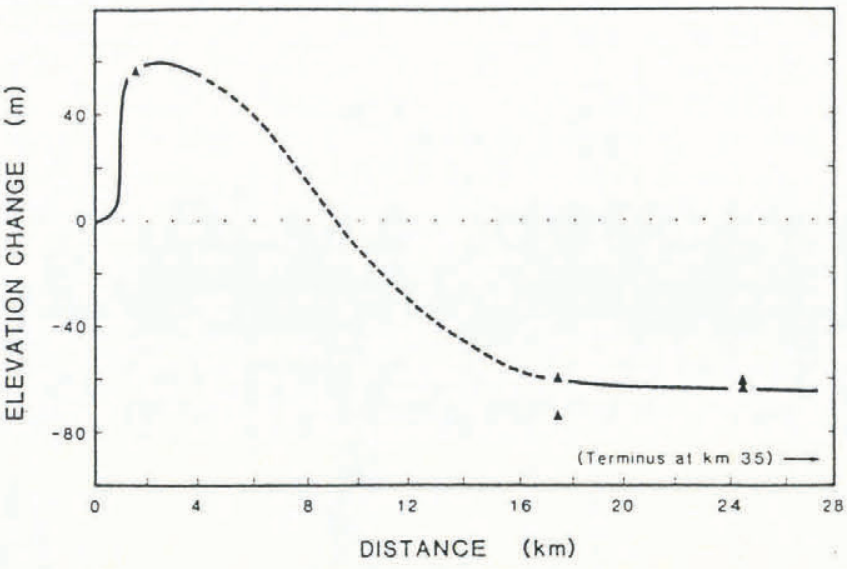

Fig. 7. Surface-elevation change from 1956 to 1982 on the center line of the east tributary of Susitna Glacier. Distance shown on the abscissa is distance from the head of the glacier.

obviously no imbalance would be observed), and the approximate quantity of ice transferred down-glacier during a surge must be known. If these factors are known, then the supply-area refill rate could be used to determine an approximate surge period. This is of course further complicated by the fact that the quantity of ice moved during different surges on the same glacier can vary considerably (e.g. Figs 2 and $6 \mathrm{~b})$.

\section{SUMMARY}

Actual ice flux and balance flux have been compared on West Fork Glacier, East Fork Glacier and the three tributaries of Susitna Glacier. The comparison is a useful tool for determining the likelihood of surge behavior, and can be used to distinguish differences in dynamics of separate tributaries of the same glacier. The mass balance and velocity data used for this comparison are admittedly quite sparse, and have large errors associated with the parameters derived from them. However, when these data are viewed in combination with those taken from aerial photographs, moraines, maps and altimetry, a reasonably consistent picture develops: West Fork Glacier is a surge-type glacier and it may be expected to surge about every $50-60$ years, as borne out by its recent behavior. The three tributaries of Susitna Glacier show markedly different dynamics. The northwest tributary shows little or no surge character; it flows normally and participates very little during surges. The east tributary exhibits a very strong surge character; it moves very slowly during the glacier's quiescent phase and is very active during surge. The northwest tributary's dynamics lie somewhere between these two; it flows rather vigorously during quiescence but also participates significantly during surge. Like West Fork Glacier, Susitna Glacier may also be expected to surge every $50-$ 60 years. This places the next surge of Susitna Glacier in the first decade of the 21st century. East Fork Glacier is not a surge-type glacier, as was found by several earlier authors (Post, 1969; Harrison and R \& M Consultants, 1982; Wilbur, 1988).

Seasonal velocity variations of these glaciers show several interesting features. Speed during early summer, at 
the resolution of these measurements, can be as much as double the winter speed. The annual velocity minimum on some glaciers occurs in late summer. This implies that these particular glaciers are sliding in winter. Moreover, although the data are limited, events of rapid motion, lasting a day or so, also occur. Finally, West Fork Glacier showed a $29 \%$ increase in speed over the 2 year period of measurement. This speed increase was measured 5 years prior to its most recent surge and is similar to Variegated Glacier's annual speed increases over several years prior to its surge (Raymond and Harrison, 1988).

\section{ACKNOWLEDGEMENTS}

The author would like to express his sincere gratitude to W. Harrison and K. Echelmeyer for their discussions, perspective and encouragement during the preparation of this manuscript, and for the comments provided by an anonymous reviewer. The excellent work of D. Johnson and C. Moore in the field provided most of the quantity and quality data that were available to work with. C. Schoch of R \& M Consultants also contributed greatly to the field efforts. Co-operating companies or agencies have been $\mathrm{R} \& \mathrm{M}$ Consultants of Anchorage, Alaska, Acres American, Inc., Harza-Ebasco Susitna Joint Venture, the Alaska Power Authority and the State of Alaska Division of Geological and Geophysical Surveys. Financial support has been from the Alaska Power Authority, the State of Alaska Division of Geological and Geophysical Surveys, the University of Alaska and the U.S. National Science Foundation, Division of Polar Programs. The preparation of this manuscript was made possible under U.S. NSF grant numbers DPP-8822624 and DPP8519110 .

\section{REFERENCES}

Bindschadler, R., W. D. Harrison, C.F. Raymond and R. Crosson. 1977. Geometry and dynamics of a surgetype glacier. J. Glaciol., 18(79), 181-194.

Clarke, G. K. C., S. G. Collins and D. E. Thompson. 1984. Flow, thermal structure, and subglacial conditions of a surge-type glacier. Can. J. Earth Sci., 21(2), 232240.

Clarke, G. K. C., J.P. Schmok, C.S. L. Ommanney and S. G. Collins. 1986. Characteristics of surge-type glaciers. J. Geophys. Res., 91(B7), 7165-7180.

Clarke, T.S. 1986. Glacier runoff, balance and dynamics in the upper Susitna River basin, Alaska. (M.S. thesis, University of Alaska.)

Clarke, T.S., D. Johnson and W.D. Harrison. 1985. Glacier runoff in the upper Susitna and MacLaren river basins, Alaska. In Dwight, L. P., ed. Proceedings. Resolving Alaska's water resources conflicts. Fairbanks, AK, University of Alaska-Fairbanks. Institute of Water Resources/Engineering Experiment Station, 99-111. (Report IWR-108.)

Clarke, T.S., D. Johnson and W.D. Harrison. 1986. Some aspects of glacier hydrology in the upper Susitna and Maclaren river basins, Alaska. In Kane, D. L., ed. Proceedings. Cold regions hydrology. American Water Resources Association, 329-337. (Technical Publications Series TPS-86-1.)
Dolgushin, L. D. and G. B. Osipova. 1973. Regime of a surging glacier between advances. International Association of Hydrological Sciences Publication 107 (Symposium at Banff 1972 - Role of Snow and Ice in Hydrology), 1150-1159.

Dolgushin, L.D. and G.B. Osipova. 1978. Balance of a surging glacier as the basis for forecasting its periodic advances. Mater. Glyatsiol. Issled. Khron. Obsuzhdeniya 32, 260-265.

Echelmeyer, K. and W.D. Harrison. 1989. Surge of West Fork Glacier, Alaska, U.S.A. (Abstract.) Ann. Glaciol., 12, 212.

Echelmeyer, K., R. Butterfield and D. Cuillard. 1987. Some observations on a recent surge of Peters Glacier, Alaska, U.S.A. J. Glaciol., 33(115), 341-345.

Harrison, W.D. 1981. Alaska Power Authority, Susitna Hydroelectric Project, Task 3. Hydrology. 1981 glacier studies. Buffalo, NY, Acres American Inc.

Harrison, W.D. and R. and M. Consultants. 1982. Alaska Power Authority, Susitna Hydroelectric Project, Task 3. Hydrology. Glacier studies. Buffalo, NY, Acres American Inc.

Harrison, W.D., L. R. Mayo and D. C. Trabant. 1975. Temperature measurements on Black Rapids Glacier, Alaska, 1973. In Weller, G. and S. A. Bowling, eds. Climate of the Arctic. Fairbanks, AK, University of Alaska. Geophysical Institute, 350-352.

Harrison, W. D., B. T. Drage, S. Bredthauer, D. Johnson, C. Schoch and A.B. Follett. 1983. Reconnaissance of the glaciers of the Susitna River basin in connection with proposed hydroelectric development. Ann. Glaciol., 4, 99-104.

Harrison, W.D., C.F. Raymond and P. MacKeith. 1986a. Short period motion events on Variegated Glacier as observed by automatic photography and seismic methods. Ann. Glaciol., 8, 82-89.

Harrison, W. D., C. F. Raymond, C. S. Moore, E. Senear and P. MacKeith. 1986b. Time lapse camera data from Variegated and other glaciers 1979-1984. Fairbanks, AK, University of Alaska. Geophysical Institute. (Report UAG-R 304.)

Hodge, S. M. 1974. Variations in the sliding of a temperate glacier. J. Glaciol., 13(69), 349-369.

Holmlund, P. 1988. Is the longitudinal profile of Storglaciären, northern Sweden, in balance with the present climate? J. Glaciol., 34(118), 269-273.

Iken, A. 1978. Variations of surface velocities of some Alpine glaciers measured at intervals of a few hours. Comparison with Arctic glaciers. Z. Gletscherkd. Glazialgeol., 13(1/2), 1977, 23-35.

Iken, A. 1981. The effect of the subglacial water pressure on the sliding velocity of a glacier in an idealized numerical model. J. Glaciol., 27(97), 407-421.

Iken, A., H. Röthlisberger, A. Flotron and W. Haeberli. 1983. The uplift of Unteraargletscher at the beginning of the melt season - a consequence of water storage at the bed? J. Glaciol., 29(101), 28-47.

Kamb, B. and 7 others. 1985. Glacier surge mechanism: 1982-1983 surge of Variegated Glacier, Alaska. Science, 227(4686), 469-479. 
Krenke, A.N. and K.P. Rototayev. 1973. A surge of the Kolka glacier and its hydrometeorological consequences. International Association of Hydrological Sciences Publication 107 (Symposium at Banff 1972 - Role of Snow and Ice in Hydrology), 1160-1171.

Mayo, L.R. 1978. Identification of unstable glaciers intermediate between normal and surging glaciers. Mater. Glyatsiol. Issled. Khron. Obsuzhdeniya 33, 133135.

Meier, M.F. and A.S. Post. 1969. What are glacier surges? Can. J. Earth Sci., 6(4), 807-817.

Nye, J.F. 1965. The flow of a glacier in a channel of rectangular, elliptic or parabolic cross-section. J. Glaciol., 5(41), 661-690.

Nye, J.F. 1958. A theory of wave formation in glaciers. International Association of Scientific Hydrology Publication 47 (Symposium at Chamonix 1958 Physics of the Movement of the Ice), 139-154.

Ommanney, C.S.L. 1980. The inventory of Canadian glaciers: procedures, techniques, progress and applications. International Association of Hydrological Sciences Publication 126 (Workshop at Riederalp 1978 - World Glacier Inventory), 35-44.
Paterson, W. S. B. 1972. Temperature distribution in the upper layers of the ablation area of Athabasca Glacier, Alberta, Canada. J. Glaciol., 11(61), 31-41.

Paterson, W. S. B. 1981. The physics of glaciers. Second edition. Oxford, etc., Pergamon Press.

Post, A.S. 1960. The exceptional advances of the Muldrow, Black Rapids, and Susitna glaciers. J. Geophys. Res., 65(11), 3703-3712.

Post, A. S. 1969. Distribution of surging glaciers in western North America. J. Glaciol., 8(53), 229-240.

Raymond, C.F. and W.D. Harrison. 1988. Evolution of Variegated Glacier, Alaska, U.S.A., prior to its surge. J. Glaciol., 34(117), 154-169.

Trabant, D.C. and L.R. Mayo. 1985. Estimation and effects of internal accumulation on five glaciers in Alaska. Ann. Glaciol., 6, 113-117.

Wilbur, S.C. 1988. Surging versus nonsurging glaciers: a comparison using morphometry and balance. (M.S. thesis, University of Alaska.)

The accuracy of references in the text and in this list is the responsibility of the authors, to whom queries should be addressed. 